\title{
FUSARIUM SPP. CONTAMINATION OF WHEAT, MAIZE, SOYBEAN, AND PEA IN CROATIA*
}

\author{
Dario IVIĆ ${ }^{1}$, Ana-Marija DOMIJAN²${ }^{2}$, Maja PERAICA², Tihomir MILIČEVIĆ ${ }^{1}$, \\ and Bogdan CVJETKOVIĆ ${ }^{1}$
}

Zagreb University Faculty of Agriculture ${ }^{1}$, Institute for Medical Research and Occupational Health ${ }^{2}$, Zagreb, Croatia

Received in March 2009

Accepted in July 2009

\begin{abstract}
From 2002 to 2008, 203 samples of wheat, maize, soybean, and pea were analysed for the presence of Fusarium species. Contamination with Fusarium spp., expressed as the percentage of seeds with Fusarium colonies, ranged from $5 \%$ to $69 \%$ for wheat, from $25 \%$ to $100 \%$ for maize, from $4 \%$ to $17 \%$ for soybean, and from $3 \%$ to $17 \%$ for pea. 187 isolates were collected and the following 19 species determined: $F$. graminearum, $F$. poae, $F$. avenaceum, $F$. verticillioides, $F$. sporotrichioides, $F$. heterosporum, $F$. crookwellense, $F$. tricinctum, $F$. semitectum, F. oxysporum, $F$. proliferatum, $F$. solani, $F$. equiseti, $F$. pseudograminearum, F. chlamydosporum, F. sambucinum, F. compactum, F. scirpi, and F. culmorum. Dominant species were $F$. graminearum on wheat ( $27 \%$ of isolates), $F$. verticillioides on maize ( $83 \%$ of isolates), F. sporotrichioides on soybean (34\% of isolates), and $F$. proliferatum on pea (29\% of isolates). Among species identified, $F$. heterosporum, F. crookwellense, F. pseudograminearum, $F$. sambucinum, and $F$. compactum have been reported for the first time in Croatia.
\end{abstract}

KEY WORDS: feed, food, fungi, mycotoxins, species identification

The genus Fusarium comprises more than 80 species of fungi, which differ considerably in their biology, ecology, and economic significance (1). Fusarium species can parasitise plants, vertebrates, insects, humans, or even other fungi, but most of them have a strong saprophytic ability and can develop on dead organic matter. Regardless of their ecological and nutritional behaviour, a great number of Fusarium species can colonise nearly all plant parts, including seed.

Different Fusarium species can produce a wide range of secondary metabolites, many of which are toxic to humans or animals (2). These mycotoxins produced on plants during vegetation can enter into

"The subject was presented at the $2^{\text {nd }}$ Croatian Scientific Symposium with International Participation Fungi and Mycotoxins - Health Aspects and Prevention, held in Zagreb, Croatia on 5 December 2008. food or feed and can cause different adverse effects on human or animal health.

Over the last twenty years, research on the genus Fusarium has intensified, especially with the Fusarium head blight (FHB) epidemics on wheat, deoxinivalenol (DON) contamination issue $(3,4)$, and the discovery of fumonisins, cancerogenic mycotoxins that are frequent in maize $(5,6)$. Interdisciplinary efforts made to solve the global problem of food and feed contamination with Fusarium mycotoxins have placed the genus Fusarium in the focus of interest of researchers and experts in mycology, agronomy, plant pathology, food technology, toxicology, and animal health.

Our Department of Plant Pathology (Zagreb University Faculty of Agriculture) had conducted mycological analysis of seed and grain of many crops from 2002 to 2008. This analysis revealed the presence of Fusarium species on wheat, barley, oat, triticale, 
maize, tobacco, bean, pea, soybean, lupin, vetch, alfalfa, clover, flax, beet, spinach and lettuce seed, and grain. The level of contamination and population structure of Fusarium spp. in these substrates on grain could predict the presence of certain Fusarium mycotoxins (7-9). This paper presents the results of a six-year analysis of wheat, maize, soybean, and pea grain contamination with Fusarium species.

\section{MATERIALS AND METHODS}

\section{Sample origin}

Samples of maize (Zea mays), wheat (Triticum aestivum), soybean (Glycine max), and pea (Pisum sativum) originated from different locations in Croatia and were collected from 2002 to 2008. Grain was sampled from fungicide efficacy trials, cultivars, or hybrid selection trials, or was sent to the Department of Plant Pathology for seed health analysis by individual people and companies. Altogether 116 wheat samples, 48 maize samples, 32 soybean samples, and 7 pea samples were analysed.

\section{Fusarium spp. quantification on grain}

One hundred seeds were prepared per each sample. Wheat and maize kernels were placed on double wet blotters, left for 24 hours at $20^{\circ} \mathrm{C}$ to $22{ }^{\circ} \mathrm{C}$, then frozen at $-20^{\circ} \mathrm{C}$ for additional 24 hours, and placed in an incubator at $21^{\circ} \mathrm{C}$ for 7 to 10 days. After the incubation, each seed was checked for the presence of fungi using stereomicroscope and light microscope. Fusarium colonies were identified by the conidia developed on grain or characteristic carmine red mycelia. If yellow or white sterile mycelial mass resembling Fusarium colony occurred on grain, fragments of mycelia were transferred to potato dextrose agar (PDA), incubated for 5 to 10 days, and then identified in culture. Contamination of sample with Fusarium spp. was expressed as the percentage of grains on which Fusarium colonies were determined. To prevent Rhizopus stolonifer or other fast-growing zygomycetous fungi to emerge from the kernels and impede detection of Fusarium spp. mycelia, the grain was surface-sterilised in $1 \% \mathrm{NaOCl}$ solution for one to three minutes, rinsed twice in sterile water, dried for one day and then placed on the blotter. One sample of maize, six samples of soybean, and two samples of pea were treated this way.

\section{Isolation and identification of Fusarium species}

Fusarium species on grain were identified on three samples of wheat from 2003, four samples of maize from 2005, five samples of soybean from 2008, and five samples of pea from 2007 and 2008. One hundred seeds were used for each sample. Wheat and maize kernels were incubated as described for the quantification of Fusarium spp. on grain. Soybean and pea grain was placed on Fusarium-selective medium (MBA) prepared according to Vujanović et al. (10). After 10 to 14 days, each Fusarium (or Fusariumresembling) colony was transferred to PDA. Cultures on PDA were incubated at $21^{\circ} \mathrm{C}$ under near-UV light, exchanging 12-hour light and dark cycles. Conidia developed in the cultures were suspended in sterile water and suspensions poured over water agar (WA) in Petri dishes. Twenty-four hours later, germinating spores were cut off from WA plates and placed on PDA. The obtained single-spore isolates were compared macroscopically, denoted, and cultivated on carnation leaf agar (CLA). The isolates were identified by the morphology of macroconidia and other morphological features according to instructions by Nelson et al. (11) and Balmas et al. (12). 2007 and 2008 isolates which were at first identified as $F$. graminum, $F$. equiseti, and $F$. graminearum were re-identified according to Leslie and Summerell (1). Identification was revised for two $F$. graminum isolates into $F$. heterosporum, one $F$. equseti into $F$. compactum, and three $F$. graminearum into $F$. pseudograminearum. All isolates have been stored on WA at $4{ }^{\circ} \mathrm{C}$ and are available at the Department of Plant Pathology.

\section{RESULTS}

Fusarium species were found in all analysed samples (Table 1). Fusarium spp. contamination of grain ranged from $3 \%$ (pea) to $100 \%$ (maize). The range of Fusarium spp. contamination was $5 \%$ to $69 \%$ on wheat grain, $25 \%$ to $100 \%$ on maize grain, $4 \%$ to $17 \%$ on soybean grain and $3 \%$ to $17 \%$ on pea grain. Among plant species analysed, the highest percentage of Fusarium spp. contamination was determined on maize grain. Taking into account all 48 samples, average contamination with Fusarium spp. on maize grain was $77 \%$. Average Fusarium spp. contamination on all samples of wheat grain was $32 \%$, on soybean grain $8 \%$, and on pea grain $8 \%$. 
Table 1 Fusarium spp. contamination (\% of grain contaminated) of wheat, maize, soybean, and pea grain in different years

\begin{tabular}{lccc}
\hline Year & $\begin{array}{c}\text { Number of samples } \\
\text { analysed }\end{array}$ & $\begin{array}{c}\text { Range of } \text { F usarium spp. } \\
\text { contamination }\end{array}$ & $\begin{array}{c}\text { Average } \text { Fusarium spp. } \\
\text { contamination }\end{array}$ \\
\hline Wheat & 80 & 15 to 61 & 38 \\
2002 & 30 & 12 to 69 & 35 \\
2003 & 3 & 5 to 17 & 10 \\
2007 & 3 & 28 to 61 & 46 \\
2008 & & & \\
\hline Maize & 44 & 71 to 100 & 91 \\
2005 & 1 & - & 89 \\
2007 & 3 & 25 to 97 & 50 \\
2008 & & & 6 \\
\hline Soybean & 2 & 4 to 8 & 5 \\
2002 & 1 & - & 9 \\
2003 & 1 & - & 9 \\
2004 & 7 & 6 to 11 & 9 \\
2005 & 7 & 6 to 17 & 7 \\
2006 & 9 & 4 to 8 & 9 \\
2007 & 5 & 6 to 12 & 7 \\
2008 & 5 & - & 8 \\
\hline Pea & 1 & - & 10 \\
2005 & 1 & 3 to 17 & \\
2007 & 5 & & \\
2008 & 5 & & \\
\hline
\end{tabular}

Nineteen Fusarium species were determined on grain of all four plant species analysed (Table 2). Eleven were determined on wheat grain, five on maize grain, 10 on soybean grain, and 10 on pea grain. The dominant species on wheat grain was $F$. graminearum, found in $27 \%$ of isolates from wheat, followed by $F$.poae $(22 \%)$, F. avenaceum $(16 \%)$, and $F$. verticillioides $(16 \%)$. The most frequent species on maize grain was $F$. verticillioides, accounting for as much as $83 \%$ of isolates from maize. On soybean grain $F$. sporotrichioides was the most common (34\%), followed by $F$. verticillioides $(15 \%), F$. equiseti $(13 \%)$, and F. semitectum (11\%). F. proliferatum and $F$. verticillioides were the dominant species on pea grain, accounting for $29 \%$ and $27 \%$ of isolates from pea, respectively.

\section{DISCUSSION}

As Fusarium spp. contamination was determined in each grain sample analysed, it is possible that toxins produced by Fusarium spp. may have been present in all samples. Theoretically, Fusarium mycotoxins can be produced on every plant and all plant parts infested by toxigenic Fusarium species. Over the last ten years, detection of mycotoxins and toxigenic Fusarium species has advanced significantly with the development of PCR-based techniques (13-16). However these techniques are still not widely used because they are expensive. This why standard mycological analysis of grain using blotters or agar media can still be useful in determining the extent of contamination with potentially toxigenic fungi such as Penicillium spp., Aspergillus spp., or Fusarium spp.

Our study suggests that the risk of contamination with Fusarium toxins is higher for maize and wheat than for soybean and pea. This is in accordance with several other studies conducted in Croatia, in which Fusarium mycotoxins were found in a high percentage of wheat or maize samples (17-20). Other Croatian studies confirmed high frequency of Fusarium species in maize grain $(19,21,22)$. The main reason for this is probably because $F$. verticillioides, $F$. proliferatum, and $F$. subglutinans can grow systemically all along the plant, without causing symptoms on ears or kernels $(5,8)$. These symptoms may also not show if these fungi grow within the kernel and produce mycotoxins 
Table 2 Fusarium species isolated from grain and toxigenic profiles of species determined

\begin{tabular}{|c|c|c|c|c|}
\hline Plant species & $\begin{array}{c}\text { Total number } \\
\text { of isolates }\end{array}$ & Species isolated & $\begin{array}{c}\text { Number of } \\
\text { isolates }\end{array}$ & $\begin{array}{c}\text { Mycotoxins potentially } \\
\text { produced }\end{array}$ \\
\hline \multirow{11}{*}{ Wheat } & \multirow{11}{*}{51} & F. graminearum & 14 & DON, NIV, ZEN \\
\hline & & F.poae & 11 & NIV, BEA \\
\hline & & F. avenaceum & 8 & MON, BEA \\
\hline & & F.verticillioides & 8 & FUM \\
\hline & & F. sporotrichioides & 3 & T2, HT2 \\
\hline & & F. heterosporum & 2 & - \\
\hline & & F. crookwellense & 1 & NIV, ZEN \\
\hline & & F.tricinctum & 1 & MON \\
\hline & & F. semitectum & 1 & MON, ZEN, BEA \\
\hline & & F. oxysporum & 1 & MON, BEA \\
\hline & & F.proliferatum & 1 & FUM, BEA, MON \\
\hline \multirow{5}{*}{ Maize } & \multirow{5}{*}{41} & F. verticillioides & 34 & FUM \\
\hline & & F. graminearum & 4 & DON, NIV, ZEN \\
\hline & & F. proliferatum & 1 & FUM, BEA, MON \\
\hline & & F. sporotrichioides & 1 & T2, HT2 \\
\hline & & F. solani & 1 & - \\
\hline \multirow{10}{*}{ Soybean } & \multirow{10}{*}{47} & F. sporotrichioides & 16 & T2, HT2 \\
\hline & & F. verticillioides & 7 & FUM \\
\hline & & F. equiseti & 6 & DAS, ZEN \\
\hline & & F. semitectum & 5 & MON, ZEN, BEA \\
\hline & & F. pseudograminearum & 3 & DON, ZEN \\
\hline & & F. chlamydosporum & 2 & MON \\
\hline & & F. sambucinum & 2 & DON, ZEN, MON \\
\hline & & F.poae & 1 & NIV, BEA \\
\hline & & F. compactum & 1 & - \\
\hline & & F. solani & 1 & MON, DAS \\
\hline \multirow{10}{*}{ Pea } & \multirow{10}{*}{48} & $F$. proliferatum & 14 & FUM, BEA, MON \\
\hline & & F. verticillioides & 13 & FUM \\
\hline & & F. sporotrichioides & 4 & $\mathrm{~T} 2, \mathrm{HT} 2$ \\
\hline & & F. scirpi & 4 & DAS, ZEN \\
\hline & & F. semitectum & 3 & MON, ZEN, BEA \\
\hline & & F. oxysporum & 3 & MON, BEA \\
\hline & & F.poae & 2 & NIV, BEA \\
\hline & & F. avenaceum & 2 & MON, BEA \\
\hline & & F. equiseti & 2 & DAS, ZEN \\
\hline & & F. culmorum & 1 & DON, NIV, ZEN \\
\hline
\end{tabular}

$B E A=$ beauvericin $; D A S=$ diacetoxyscirpenol; $D O N=$ deoxynivalenol; $F U M=$ fumonisins; $H T 2=H T-2$ toxin; $M O N=$ moniliformin; $N I V=$ nivalenol; $T 2=T-2$ toxin; $Z E N=$ zearalenone

in an apparently healthy grain. Our 2007 and 2008 samples were asymptomatic, but high percentage of Fusarium spp. was still found on grain. The 2005 maize samples were mostly collected from plants affected with Fusarium ear rot (8).

Contamination of wheat samples in our study was high in 2002, 2003, and 2008, and relatively low in 2007. Contamination of wheat grain with Fusarium spp. highly depends on environmental conditions from flowering to the harvest (3). Environmental conditions affect colonisation of wheat heads with different Fusarium spp. Regardless, Fusarium species are expected to colonise wheat grain every year and in every location where wheat is grown. Other studies from Croatia confirm that Fusarium spp. are among the most common fungi on wheat grain $(23,24)$. 
In contrast to cereals, Fusarium spp. contamination of soybean and pea grain has received less attention. Judging from Fusarium spp. infestation, the risk of contamination with Fusarium toxins might be lower for soybean and pea than for maize and wheat. Nevertheless, several studies from different countries have confirmed the presence Fusarium mycotoxins in soybean and pea. Schollenberger et al. reported T-2 tetraol, HT-2 toxin, deoxynivalenol (DON), and zearalenone (ZEN) in soya meal. Interestingly, none of the pea samples contained Fusarium toxins (25). Park et al. (26) confirmed the toxicity of Fusarium isolates from soybean grain in experiments with rats, while Martinelli et al. (27) confirmed the ability of $F$. graminearum to produce DON and nivalenol (NIV) in soybean pots and seeds during vegetation. Clear et al. (28) detected DON and HT-2 toxin in soybean seeds, while Saber et al. (29) detected T-2 toxin in pea. Ćosić et al. (30) reported much lower Fusarium spp. contamination of soybean seed than in our study, but the presence of these fungi confirm that Fusarium toxins could be found on soybean in Croatia.

Nineteen Fusarium species found on wheat, maize, soybean, and pea grain show that this genus infests plant parts in a rich variety of species (31). Population structure of Fusarium spp. on grain can indicate which types of mycotoxins could be expected in a sample, based on the toxigenic profile of each species. Fusarium species found on grain in this study according to Leslie and Summerell (1) can produce DON, NIV, ZEN, fumonisins (FUM), beauvericin (BEA), diacetoxyscirpenol (DAS), HT-2 toxin (HT2), $\mathrm{T}-2$ toxin (T2), moniliformin (MON), and a range of other less investigated toxins (1). Exposure to these toxins can seriously affect human or animal health (5$7,17,32-34)$. ZEN is an immunotoxic, haematotoxic, hepatotoxic, and genotoxic oestrogenic toxin (32) which can cause infertility, hyperoestrogenism or poor performance in domesticated animals (7, 32 ), and has been implicated in hyperoestrogenic syndromes in humans (32). MON is a cytotoxic and haematotoxic toxin which can cause poor performance in livestock or mortality in animals (7), and has been suspected as a cause of human heart disorder known as Keshan disease (7). BEA is cytotoxic and can cause apoptosis of murine and human cell lines (7). FUM is a cancer-promoting hepatotoxic and nephrotoxic toxin $(5,6)$, and can cause fatal animal diseases like leukoencephalomalacia in horses and pulmonary oedema in swine (5). Trichothecenes like DON, NIV, DAS, HT2, or T2 are haematotoxic, cytotoxic, immunotoxic and embryotoxic $(7,33)$, and can cause reduced growth, postnatal mortality, foetal skeleton abnormalities, leucopenia, intrauterine growth retardation, pulmonary adenomas, or epithelial hyperplasia in animals $(33,34)$.

The dominance of $F$. verticillioides in maize grain in our study is in accordance with other studies conducted in Croatia $(21,22,24)$. Its toxigenic profile implies that the most common mycotoxins in maize should be fumonisins or other toxins produced by this species. Research in in Croatia has confirmed this assumption; Domijan et al. (19) found $\mathrm{FB}_{1}$ in all tested samples, while Jurjević et al. (20) also found beauvericin

In our study, $F$. graminearum was the most common species in wheat grain. These results are in accordance with Ćosić et al. (24) and Jurković et al. (35), confirming that $F$. graminearum is the dominant species on wheat in Croatia. The most important mycotoxins produced by $F$. graminearum are DON and ZEN. Several Croatian studies $(17,18,36)$ have confirmed these mycotoxins as very frequent on wheat in Croatia.

$F$. poae, $F$. avenaceum, and $F$. verticillioides were relatively common on wheat in our study. $F$. avenaceum and $F$. verticillioides were also common in the study of Ćosić et al. (24). Their toxigenic profile of $F$. avenaceum and $F$. verticillioides implies that MON and FUM could be rather common in Croatian wheat. While MON is detected in wheat grain in many countries (9), fumonisins in wheat have been poorly investigated. Bottalico and Perrone (9) suggested that $\mathrm{FB}_{1}$ could occur in wheat and other small-grain cereals.

A relatively high percentage of $F$. sporotrichioides in two soybean samples and of $F$. proliferatum and $F$. verticillioides in three pea samples point to a risk of $\mathrm{T}-2$ toxin or fumonisin in these samples. The adverse effects of these two mycotoxins are well known in animals $(5,7,32-34)$, and their presence in soybean or pea intended for human consumption could human health at risk. This calls for further research and surveillance of Fusarium mycotoxins in crops other than cereals in Croatia.

To the best of our knowledge, some of the Fusarium species have been reported by this study for the first time in Croatia. Although Fusarium species were often reported by other authors using different older names, no records have been found in Croatia of $F$. heterosporum, $F$. crookwellense, $F$. pseudograminearum, $F$. sambucinum, and $F$. 
compactum or of their synonyms. Save for $F$. heterosporum, all of these species are potentially toxigenic $(1,2)$.

\section{REFERENCES}

1. Leslie JF, Summerell BA. The Fusarium Laboratory Manual. Ames (IA): Blackwell Publishing Ltd; 2006.

2. Desjardins AE. Fusarium Mycotoxins: Chemistry, Genetics and Biology. St. Paul (MN): APS Press; 2005.

3. McMullen M, Jones R, Gallenberg D. Scab of wheat and barley: a re-emerging disease of devastating impact. Plant Dis 1997;81:1340-8

4. Parry DW, Jenkinson P, McLeod L. Fusarium ear blight (scab) in small grains cereals-a review. Plant Pathol 1995;44:207-238.

5. Munkvold GP, Desjardins AE. Fumonisins in maize - Can we reduce their occurence? Plant Dis 1997;81:556-65.

6. Gelderblom WCA, Jaskiewicz J, Marasas WFO, Thie PG, Horak RM, Vleggar R, Kriek NPJ. Fumonisins-novel mycotoxins with cancer-promoting activity produced by Fusarium moniliforme. Appl Environ Microbiol 1988;54:1806-11.

7. Logrieco A, Bottalico A, Mulé G, Moretti A, Perrone G. Epidemiology of toxigenic fungi and their associated mycotoxins for some Mediterranean crops. Eur J Plant Pathol 2003;109:645-67.

8. Logrieco A, Mulè G, Moretti A, Bottalico A. Toxigenic Fusarium species and mycotoxins associated with maize ear rot in Europe. Eur J Plant Pathol 2002; 108:597-609.

9. Bottalico A, Perrone G. Toxigenic Fusarium species and mycotoxins associated with head blight in small-grain cereals in Europe. Eur J Plant Pathol 2002;108:611-624.

10. Vujanovic V, Hamel C, Jabaji-Hare S, St-Arnaud M. Development of a selective myclobutanil agar (MBA) medium for the isolation of Fusarium species from asparagus fields. Can J Microbiol 2002;48:841-7.

11. Nelson PE, Toussoun TA, Marasas WFO. Fusarium SpeciesAn Illustrated Manual for Identification. London: The Pennsylvania State University Press; 1983.

12. Balmas V, Santori A, Corazza L. Le specie di Fusarium più comuni in Italia - Suggerimenti per il loro riconoscimento [The most common Fusarium species in Italy: Suggestions for their identification, in Italian]. Petria 2000;10(Suppl.1):160.

13. Baird R, Abbas HK, Windham G, Williams P, Baird S, Ma P, Kelley R, Hawkins L, Scruggs M. Identification of select fumonisin forming Fusarium species using PCR applications of the polyketide synthase gene and its relationship to fumonisin production in vitro. Int J Mol Sci 2008;9:55470.

14. Nicholson P, Simpson DR, Wilson AH, Chandler E, Thomsett $M$. Detection and differentiation of trichothecene and enniatin-producing Fusarium species on small-grain cereals. Eur J Plant Pathol 2004;110:503-14.

15. Niessen L, Schmidt H, Vogel RF. The use of tri5 gene sequences for PCR detection and taxonomy of trichotheceneproducing species in the Fusarium section Sporotrichiella. Int J Food Microbiol 2004;95:305-19.
16. Edwards SG, Pirgozliev SR, Hare MC, Jenkinson P. Quantification of trichothecene-producing Fusarium species in harvested grain by competitive PCR to determine the efficacies of fungicides against Fusarium head blight of winter wheat. Appl Environ Microbiol 2001;67:1575-80.

17. Pepeljnjak S, Cvetnić Z, Šegvić Klarić M. Okratoksin A i zearalenon: kontaminacija žitarica i krmiva u Hrvatskoj (1977-2007) i utjecaj na zdravlje životinja i ljudi [Ochratoxin A and zearalenone: Cereals and feed contamination in Croatia (1977-2007) and influence on animal and human health, in Croatian]. Krmiva 2008;50:147-59.

18. Sokolović M, Šimpraga B. Survey of trichothecene mycotoxins in grains and animal feed in Croatia by thin layer chromatography. Food Contr 2006;17:733-40.

19. Domijan A-M, Peraica M, Jurjević Ž, Ivić D, Cvjetković $B$. Survey of fumonisin $\mathrm{B}_{1}$, fumonisin $\mathrm{B}_{2}$, zearalenone, and ochratoxin A contamination of maize in Croatia. Food Addit Contam 2005;22:677-80.

20. Jurjević Ž, Solfrizzo M, Cvjetković B, De Girolamo A, Visconti A. Occurrence of beauvericin in corn from Croatia. Food Tech Biotechnol 2002;40:91-4.

21. Cvetnić Z, Pepeljnjak S, Šegvić M. Toxigenic potential of Fusarium species isolated from non-harvested maize. Arh Hig Rada Toksikol 2005; 56:275-80.

22. Šegvić M, Pepeljnjak S. Distribution and fumonisin $B_{1}$ production capacity of Fusarium moniliforme isolated from corn in Croatia. Period Biol 2003;105:275-9.

23. Ćosić J, Jurković D, Vrandečić K, Šimić B. Pathogenicity of Fusarium species to wheat and barley ears. Cereal Res Commun 2007;35:529-32.

24. Ćosić J, Vrandečić K, Svitlica B. Fusarium vrste izolirane s pšenice i kukuruza u istočnoj Hrvatskoj [Fusarium species isolated from wheat and corn in Eastern Croatia, in Croatian]. Poljoprivreda 2004;10:5-8.

25. Schollenberger M, Müller H-M, Rüfle M, Suchy S, Plank $\mathrm{S}$, Drochner W. Natural occurence of 16 Fusarium toxins in grains and feedstuffs of plant origin from Germany. Mycopathologia 2006;161:43-52.

26. Park J-S, Lee K-R, Kim J-C, Lim S-H, Seo J-A, Lee Y-W. A hemorrhagic factor (apicidin) produced by toxic Fusarium isolates from soybean seeds. Appl Environ Microbiol 1999;65:126-30.

27. Martinelli JA, Bocchese CAC, Xie W, O'Donnell K, Kistler HC. Soybean pod blight and root rot caused by lineages of Fusarium graminearum and the production of mycotoxins. Fitopatol Brasil 2004; 29:492-8.

28. Clear RM, Nowicki TW, Daun JK. Soybean seed discoloration by Alternaria spp. and Fusarium spp., effects on quality and production of fusariotoxins. Can J Plant Pathol 1989;11:30812.

29. Saber SM, Aboul-Nasr MB, El-Maghraby OMO. Contamination of pea (Pisum sativum L.) seeds by fungi and mycotoxins. Afr J Mycol Biotechnol 1998; 6:53-64.

30. Ć́osić J, Vrandečić K, Jurković D, Ereš I, Poštić J. Parazitna mikopopulacija zrna soje [Parasite mycopopulation of soybean grain, in Croatian]. Poljoprivreda 2008;14:5-8.

31. Summerell BA, Salleh B, Leslie JF. An utilitarian approach to Fusarium identification. Plant Dis 2003;87:117-28.

32. Zinedine A, Soriano JM, Moltó JC, Mañes J. Review on the toxicity, occurrence, metabolism, detoxification, regulations and intake of zearalenone: An oestrogenic mycotoxin. Food Chem Toxicol 2007;45:1-18. 
33. Schlatter J. Toxicity data relevant for hazard characterization. Toxicol Lett 2004;153:83-9.

34. Sokolović M, Garaj-Vrhovac V, Šimpraga B. T-2 toxin: incidence and toxicity in poultry. Arh Hig Rada Toksikol 2008;59:43-52.
35. Jurković D, Cosić J. Influence of Fusarium species on wheat seed germination. Cereal Res Comm 1997;25:761-2.

36. Ćosić J, Jurković D, Vrandečić K. Influence of environmental factors on deoxynivalenol content in wheat flour. Cereal Res Comm 2006;34:17-20. 


\section{Sažetak}

\section{KONTAMINACIJA ZRNA PŠENICE, KUKURUZA, SOJE I GRAŠKA VRSTAMA FUSARIUMA U HRVATSKOJ}

U periodu od 2002. do 2008. g. analizirana je prisutnost vrsta Fusariuma na 208 uzoraka zrna pšenice, kukuruza, soje i graška. Kontaminacija vrstama Fusariuma, izražena kao postotak sjemenki s kolonijama Fusarium spp., kretala se od $5 \%$ do $69 \%$ na pšenici, od $25 \%$ do $100 \%$ na kukuruzu, od $4 \%$ do $17 \%$ na soji te od $3 \%$ do $17 \%$ na grašku. Prosječna kontaminacija vrstama Fusariuma u različitim godinama varirala je od $10 \%$ do $46 \%$ na pšenici, od $50 \%$ do $91 \%$ na kukuruzu, od $5 \%$ do $9 \%$ na soji te od $7 \%$ do $10 \%$ na grašku. Vrste Fusariuma koje se javljaju na zrnu izolirane su i determinirane s odabranih uzoraka pšenice, kukuruza, soje i graška. Skupljeno je 187 izolata, a utvrđeno je 19 vrsta: F. graminearum, $F$. poae, $F$. avenaceum, $F$. verticillioides, $F$. sporotrichioides, $F$. heterosporum, $F$. crookwellense, $F$. tricinctum, F. semitectum, F. oxysporum, F. proliferatum, F. solani, F. equiseti, F. pseudograminearum, F. chlamydosporum, F. sambucinum, F. compactum, F. scirpi i $F$. culmorum. Dominantne vrste bile su $F$. graminearum na pšenici (27\% izolata), F. verticillioides na kukuruzu ( $83 \%$ izolata), $F$. sporotrichioides na soji (34 \% izolata) te $F$. proliferatum na grašku (29 \% izolata). U Hrvatskoj su prvi put utvrđene vrste F. heterosporum, F. crookwellense, F. pseudograminearum, F. sambucinum i F. compactum.

KLJUČNE RIJEČI: determinacija vrsta, gljive, hrana, krma, mikotoksini

\section{CORRESPONDING AUTHOR:}

Dario Ivić

University of Zagreb, Faculty of Agriculture

Svetošimunska 25, 10000 Zagreb, Croatia

E-mail:divic@agr.hr 